\title{
Lupus-like nephritis with positive anti-neutrophil cytoplasmic antibodies and negative antinuclear antibodies
}

\author{
Nefrite semelhante à lúpica com anticorpos citoplasmáticos anti- \\ neutrófilos positivos e anticorpos antinucleares negativos
}

\begin{abstract}
Authors
Joana Eugénio Santos ${ }^{1}$ (D)

Rita Vicente ${ }^{1(1)}$

Beatriz Malvar ${ }^{1}$ (iD

Iolanda Santos ${ }^{1}$ (D)

Miguel Coimbra ${ }^{1(D)}$

Manuel Amoedo ${ }^{1}$ (iD

Carlos Pires ${ }^{1 \text { (i) }}$

${ }^{1}$ Hospital Espírito Santo de Évora, Department of Nephrology, Évora, Portugal.
\end{abstract}

Submitted on: 05/25/2020.

Approved on: 09/01/2020.

\section{Correspondence to: \\ Joana Eugénio Santos. \\ E-mail: joana.eugenio.santos@gmail.com}

DOI: https://doi.org/10.1590/2175-8239-JBN-2020-0114

\section{Abstract}

Antineutrophil cytoplasmic antibodies (ANCAs) are associated with small vessel vasculitis but their prevalence is not rare in other immune diseases. In lupus nephritis (LN), their pathological role and clinical relevance have been the target of controversial views.

We present a case of acute kidney injury and nephrotic syndrome in a young woman with diffuse global proliferative and membranous nephritis on her kidney biopsy, showing a full-house immunofluorescence pattern, very allusive of class IV + V LN, but lacking associated clinical criteria and laboratory findings to support the diagnosis of systemic lupus erythematosus (SLE). Furthermore, the patient presented with high titers of ANCA, steadily decreasing alongside the renal function and proteinuria improvements, with mycophenolate mofetil (MMF) and steroid treatment.

The authors believe this is a case of lupus-like nephritis, in which ANCAs are immunological markers, although they are not directly involved in the pathogenesis.

Keywords: Antineutrophil Cytoplasmic Antibodies, Antinuclear Autoantibodies; Lupus Nephritis; Lupus Erythematosus, Systemic; Glomerulonephritis.

\section{INTRODUCTION}

Lupus nephritis (LN) is a complex immune glomerulonephritis that often complicates the clinical course of systemic lupus erythematosus (SLE). It occurs in $40 \%$ of SLE patients and is one of the most severe manifestations of the disease. It is a well-defined histological disease, characterized by deposition of immune complexes, at mesangial, subendothelial, and subepithelial locations of the

\section{Resumo}

Os anticorpos anticitoplasma de neutrófilos (ANCAs) estão associados à vasculite de pequenos vasos, no entanto, a sua prevalência não é rara em outras doenças imunológicas. $\mathrm{Na}$ nefrite lúpica (LN), o seu papel patológico e relevância clínica têm sido alvo de pontos de vista controversos.

Apresentamos um caso de lesão renal aguda e síndrome nefrótica em uma jovem com nefrite proliferativa difusa e membranosa em sua biópsia renal, muito alusivo a NL classe IV + V, com um padrão full house na imunofluorescência, mas sem critérios clínicos e achados laboratoriais para corroborar o diagnóstico de lúpus eritematoso sistêmico (LES). Não obstante, a paciente apresentou títulos elevados de ANCA, que diminuiram progressivamente com a melhoria da função renal e da proteinúria, após tratamento com micofenolato de mofetil (MMF) e esteróide. Os autores acreditam que se trata de um caso de nefrite semelhante à nefrite lúpica, em que os ANCAs são marcadores imunológicos, embora não estejam diretamente envolvidos na patogênese.

Descritores: Anticorpos Anticitoplasma de Neutrófilos; Anticorpo Antinuclear; Nefrite Lúpica; Lúpus Eritematoso Sistêmico; Glomerulonefrite.

glomeruli, and also extraglomerular alterations. Besides, these deposits may stain dominantly for IgG, and contain co-deposits of immunoglobulin $\mathrm{A}$, immunoglobulin $\mathrm{M}, \mathrm{C} 3$, and $\mathrm{C} 1 \mathrm{q}$, yielding the so-called "full house" immunofluorescence pattern, which is highly suggestive of LN.

There are cases of characteristic LN lacking clinical criteria for SLE, complicating the diagnosis. Such patients 
with microscopic and immunofluorescence findings, highly favoring the diagnosis of LN but lacking further signs, symptoms, or serologies, which confirm the diagnosis of SLE, may present distinct nephropathy. Other authors use two different terminologies concerning the disease: "lupus-like nephritis" and "idiopathic non-lupus full-house nephropathy"-2.

The purpose of this article is to present a diagnosis of lupus-like nephritis, whose serological markers appear to be antineutrophil cytoplasmic antibodies (ANCA) instead of antinuclear autoantibodies (ANA), although they did not play a clear pathogenic role.

\section{Case Presentation}

A 31-year-old Caucasian female presented with worsening lower limb and periorbital edema and fatigue. She had undergone routine blood and urine tests 4 months earlier, which had shown acute kidney injury, with a serum creatinine $(\mathrm{sCr})$ of $1.8 \mathrm{mg} / \mathrm{dL}$ and new-onset microscopic hematuria.

Macroscopic urine abnormalities, oliguria, and lower urinary tract symptoms were absent. The patient also lacked skin lesions, joint pain or swelling, photosensitivity, oral ulcers, dyspnea, chest pain, fever, and constitutional symptoms. She was overweight (BMI $33.8 \mathrm{~kg} / \mathrm{m}^{2}$ ) and had active smoking habits. Family history was negative for renal, autoimmune, or neoplastic diseases.

Physical examination was unimpressive other than high blood pressure and lower extremity $3+$ pitting edema, extending from the mid-thigh to the feet.

Laboratory evaluation revealed kidney function deterioration (sCr $3.1 \mathrm{mg} / \mathrm{dL}$ and urea $100 \mathrm{mg} / \mathrm{dL}$ ), normocytic and normochromic anemia (hemoglobin $9.4 \mathrm{~g} / \mathrm{dL}$ ), hypoalbuminemia of $1.5 \mathrm{~g} / \mathrm{dL}$ and hyperlipidemia (total cholesterol $236 \mathrm{mg} / \mathrm{dL}$ ). The remaining hematological series were unaffected. Her urinalyses presented significant proteinuria $(>1000 \mathrm{mg} / \mathrm{dL}$ ) and $>20$ red blood cells per high power field, $>50 \%$ dysmorphic. Heavy proteinuria was confirmed (19 $\mathrm{g}$ of protein excretion) in a 24 -hour urine collection. On renal ultrasonography, kidneys had normal size and structure, with only a slight increase in parenchymal echogenicity.
Further autoimmune workup revealed low complement titers $(45 \mathrm{mg} / \mathrm{dL}$ for $\mathrm{C} 3$ and $6 \mathrm{mg} / \mathrm{dL}$ for C4 fractions), and a positive ANCA test, with a very high titer (319 UI/L). She was negative for ANA and, consequently extractable nuclear antigen panel, antiphospholipid and lupus anticoagulant antibodies, anti-dsDNA, AMA, and anti-LLM. The ANCA found had a perinuclear pattern in immunofluorescence and reactivity against myeloperoxidase antigens (MPO-ANCA) in enzyme-linked immunosorbent assay. Human immunodeficiency virus and hepatitis screening tests showed no previous or current infections.

Kidney biopsy (Figure 1) was performed, revealing active global endocapillary and mesangial hypercellularity, and a diffuse thickening of the glomerular wall with "spikes" on light microscopy. On immunofluorescence there were diffuse mesangial, subendothelial, and subepithelial immune deposits, in "full-house nephropathy" pattern. The pathological diagnosis was consistent with class IVa and V LN.

Intravenous methylprednisolone was prescribed in pulses for 3 consecutive days, followed by $1 \mathrm{mg} /$ $\mathrm{kg}$ oral prednisolone and $3 \mathrm{~g}$ MMF per day. By the second month of treatment, there was a modest improvement in proteinuria and kidney function (24$\mathrm{h}$ urine protein excretion and $\mathrm{sCr}$ decreased to $13 \mathrm{~g}$ and $1.8 \mathrm{mg} / \mathrm{dL}$ respectively) and there were fewer dysmorphic red blood cells in the urinary sediment. The immune response was also positive: MPO-ANCA titers fell to $33 \mathrm{IU} / \mathrm{L}$ and serum complement levels progressively increased.

The patient's recovery was remarkable in the following 4 months. On the $6^{\text {th }}$ month of immunosuppressive (IS) therapy (after prednisolone slow tapering in the previous months to $5 \mathrm{mg} /$ day), there was a complete remission with $\mathrm{sCr} 1.0$ $\mathrm{g} / \mathrm{dL}$, proteinuria $0.6 \mathrm{~g} / 24$ hour-urine, resolution of microscopic hematuria, and normalization of serum complement levels. The titers of MPOANCA steadily declined and MMF was tapered to a maintenance dose of $500 \mathrm{mg}$ twice daily. SLE associated antibodies, ANA, and dsDNA remained negative. 


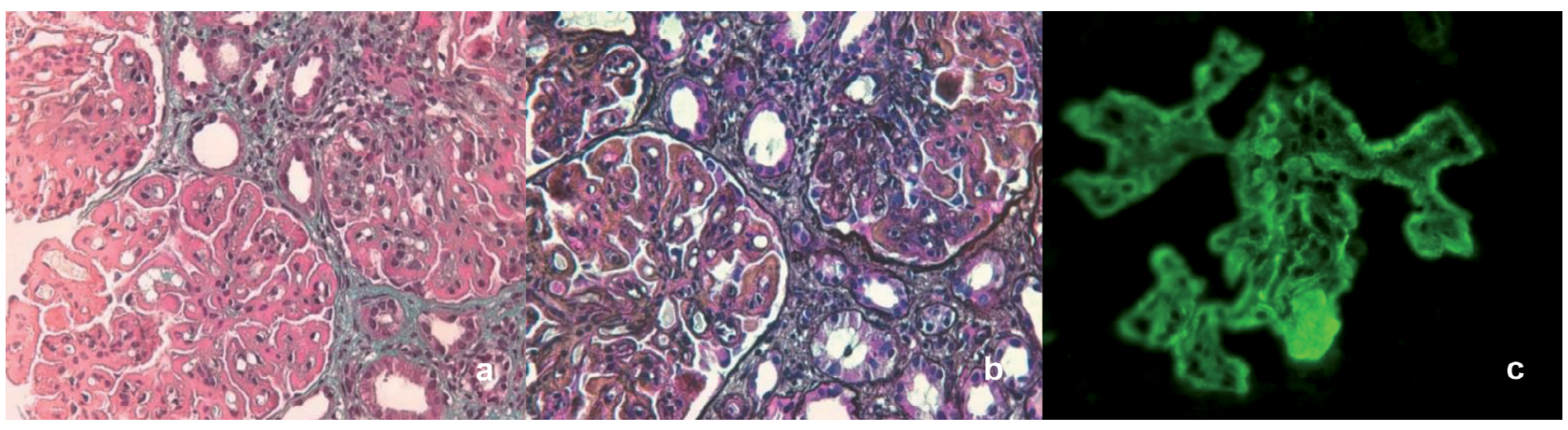

Figure 1. Image a (trichrome stain, $\mathrm{x} 400$ ) and b (silver methenamine stain, $\mathrm{x} 400$ ) shows endocapillary hypercellularity and prominent subendothelial deposits ("wire loops"). It shows a lobular expansion and increases of mesangial matrix, imparting a membranoproliferative glomerulonephritislike appearance. We can see also global and diffuse thickening of the glomerular basal membrane with granular subepithelial deposits (mainly in trichrome) with silver-positive spikes. Tubules and interstitium present with extended mononuclear infiltrate and $60 \%$ of tubulointerstitial fibrosis. Image c (immunofluorescence, x400) shows IgG parietal granular deposits in glomeruli accompanied by IgA, IgM, C3, C1q, kappa, and lambda deposits in a full-house pattern.

After 2 years of a complete sustained response, with a daily urine protein excretion of $300 \mathrm{mg}$, no hematuria, and normal kidney function, ANCA titers became negative. The patient then switched to azathioprine, motivated by her wishes to conceive. The patient has now 7 years of follow-up on remission of her nephritis. Throughout all of the follow-up period, there have never been signs of systemic vasculitis, and the patient has never experienced extrarenal manifestations of SLE or nephritis flare.

\section{Discussion}

ANAs are thought to play an essential role in the pathogenesis of LN but its pathogenesis remains incompletely understood. The theory describing that immune complexes in circulation become passively trapped in glomeruli is not supported by current evidence and is currently considered unlikely ${ }^{5}$.

The recent discovery of a familiar form of SLE, linked to a mutation of the gene encoding DNase $1 \mathrm{~L} 3^{6}$, and Sisirak et al.'s report of an experimental nephritis with autoimmunity to DNA caused by DNase 1L3 deficience DNase $1 \mathrm{~L} 3^{7}$ have altogether proved that gene deficiencies in chromatin metabolism may result in a lupus-like phenotype. Chromatin fragments are released from dying renal cells, not appropriately degraded during the programmed cell death process because of the acquired loss of the renal endonuclease DNasel. These fragments are then targeted by antichromatin (anti-nucleosome) antibodies, including anti-dsDNA. Also, the accumulation of neutrophil extracellular traps (NETs) deposits in the glomerular capillaries, prompting tissue injury and further cell death $^{8}$.
Some animal models of LN demonstrated that autoreactive $\mathrm{T}$ cells-induced damage accounted for a significant part of the kidney injury ${ }^{9}$, proving that crossreaction of anti-dsDNA antibodies with intrinsic renal antigens is not essential for the development of $\mathrm{LN}^{10}$. Therefore, the absence of circulating anti-chromatin antibodies is not a reason to rule out this diagnosis.

Patients with active LN may have other autoantibodies, including ANCA ${ }^{11}$. ANCA's presence in $\mathrm{LN}$ patients has been the target of controversial views concerning its clinical relevance and role ${ }^{12}$. Retrospective studies found a high prevalence of ANCA in $\mathrm{LN}^{13}$ and a positive correlation with disease activity and severity. A recent report showed that ANCAs were associated with more endocapillary hypercellularity, necrosis, crescent formation, interstitial inflammation, tubular atrophy, and interstitial fibrosis ${ }^{14,15}$. On the other hand, MPO-ANCA were more likely to have the last two characteristics, and lower titers of ANA or antidsDNA at the time of biopsy ${ }^{16}$.

Independently of ANCA presence, features of vasculitis such as hyaline and non-inflammatory necrotizing lesions, lymphocytic infiltration of the vessel wall, and more rarely arteriolar thrombi may all be found in $\mathrm{LN}^{17}$. In our patient's nephritis, in spite of apparent involvement of MPO-ANCA, there were no characteristic necrotizing lesions on her biopsy. ANCAs have been linked to conditions with increased turnover and impaired non-apoptotic clearance of neutrophils in probable relation with NETs, which act as prominent autoantigens, leading to diseaserelevant autoantibody production ${ }^{18}$ not leading to the development of significant histological findings. 
We were faced with biopsy-proven lupus-like nephritis, with circulating ANCA, without SLE diagnostic criteria. Although the diagnosis of SLE cannot be established solely based upon renal biopsy findings, some pathological findings of $\mathrm{LN}$ often exclude other diagnoses. That is the case of overlapping glomerular membranous and diffuse proliferative lesions, and the so-called "full-house" immunostaining, both present in the kidney biopsy of this patient.

This pathological pattern is not specific for LN. In a young person, after dropping HCV and HIV immune complex-mediated glomerulonephritis, infection-related glomerulonephritis and fibrillary glomerulonephritis, a diagnosis of lupus-like nephritis is more likely. In our patient, the time of disease outbreak, the absence of dysproteinemia, malignancy and other auto-immune diseases, as well as the remission of the disease with MMF and corticosteroids, made the fibrillary glomerulonephritis diagnosis unlikely, once it is characterized by a poor prognosis, with a progress to end-stage renal disease within few years ${ }^{19}$.

In this patient, not only was circulating ANCA detected but also its levels correlated with disease activity: extremely positive at the time of diagnosis, progressively declining with disease improvement and becoming negative at clinical remission. It did not have a clear pathogenic role, and its frequency can be explained by NETosis, which provide a source of autoantigens.

The renal-limited nature of the patient's disease, without further signs or symptoms of SLE, and negative anti-chromatin autoantibodies, makes the diagnosis of SLE unviable. However, the negative serology does not exclude $\mathrm{LN}$, as it can be explained by autoreactive T cells, ANA's entrapped in circulating immune complexes, low levels of antibodies or their loss through the kidney in patients with severe proteinuria $^{20}$.

In conclusion, the authors believe that it is a case of lupus-like nephritis with circulating ANCA and good prognosis. After careful etiological investigation and under favorable and sustained clinical response to MMF and steroids, lupus-like nephritis is the most likely situation, in possible relation with SLE. Once antinuclear antibodies, symptoms, and signs of the disease become detectable after several years of follow-up, the authors suggest patients' monitoring for the development of SLE.

\section{Author's Contribution}

Joana Eugénio Santos: Conceptualization, data curation, methodology, project administration, resources, and writing of the original draft. Rita Vicente: Conceptualization, methodology, and writing of the original draft. Beatriz Malvar: project administration, writing review, and edition. Iolanda Santos: Methodology, and resources. Miguel Coimbra: Conceptualization and methodology. Manuel Amoedo: Supervision and validation. Carlos Pires: Validation. All authors approved the manuscript and its submission, and none has any conflicts of interest to disclose.

\section{CONFLICT OF INTEREST}

The authors declare that they have no conflict of interest related to the publication of this manuscript.

\section{References}

1. Mirabelli G, Cannarile F, Bruni C, Vagelli R, De Luca R, Carli L. One year in review 2015: systemic lupus erythematosus. Clin Exp Rheumatol. 2015 Apr;33(3):414-25.

2. Huerta A, Bomback AS, Liakopoulos V, Palanisamy A, Stokes MB, D'Agati VD, et al. Renal-limited 'lupus-like' nephritis. Nephrol Dial Transplant. 2012 Jun;27(6):2337-42.

3. Simmons SC, Smith ML, Chang-Miller A, Keddis MT. Antinuclear antibody-negative lupus nephrtitis with full house nephropathy: a case report and review of the literature. Am J Nephrol. 2015;42(6):451-9.

4. Baskin E, Agras PI, Menekse N, Ozdemir H, Cengiz N. Fullhouse nephropathy in a patient with negative serology for lupus. Rheumatol Int. 2007 Jan;27(3):281-4.

5. Borchers AT, Leibushor N, Naguwa SM, Cheema GS, Shoenfeld Y, Gershwin ME. Lupus nephritis: a critical review. Autoimmun Rev. 2012 Dec;12(2):174-94.

6. Al-Mayouf SM, Sunker A, Abdwani R, Al Abrawi S, Almurshedi $\mathrm{F}$, Alhashmi N, et al. Loss-of-function variant in DNASE1L3 causes a familial form of systemic lupus erythematosus. Nat Genet. 2011 Oct;43(12):1186-8.

7. Sisirak V, Sally B, D’Agati V, Martinez-Ortiz W, Özçakar ZB, David J, et al. Digestion of chromatin in apoptotic cell microparticles prevents autoimmunity. Cell. 2016 Jun;166(1):88-101.

8. Nishi H, Mayadas TN. Neutrophils in lupus nephritis. Curr Opin Rheumatol. 2019 Mar;31(2):193-200.

9. Li S, Holdsworth SR, Tipping PG. Antibody independent crescentic glomerulonephritis in mu chain deficient mice. Kidney Int. 1997 Mar;51(3):672-8.

10. Kalaaji M, Fenton KA, Mortensen ES, Olsen R, Sturfelt G, Alm $\mathrm{P}$, et al. Glomerular apoptotic nucleosomes are central target structures for nephritogenic antibodies in human SLE nephritis. Kidney Int. 2007 Apr;71(7):664-72.

11. Amann K. Do ANCAs make the difference in lupus nephritis?. Kidney Int. 2017 Nov;92(5):1048-50.

12. Wang Y, Huang X, Cai J, Xie L, Wang W, Tang S, et al. Clinicopathologic characteristics and outcomes of lupus nephritis with antineutrophil cytoplasmic antibody, a retrospective study. Medicine (Baltimore). 2016 Jan;95(4):e2580.

13. Sanchez C, Rebolledo A, Gahona J, Rojas M, Jiménez R, Bojórquez A. Post-transplant immune complex nephritis in a patient with systemic lupus erythematosus associated with ANCA vasculitis. Pediatr Transplant. 2017 May;21(3):e12895. 
14. Turner-Stokes T, Wilson HR, Morreale M, Nunes A, Cairns T, Cook HT, et al. Positive antineutrophil cytoplasmic antibody serology in patients with lupus nephritis is associated with distinct histopathologic features on renal biopsy. Kidney Int. 2017 Nov;92(5):1223-31.

15. Li C, Zhou M, Liang DD, Wang JJ, Yang J, Zeng CH, et al. Treatment and clinicopathological characteristics of lupus nephritis with anti-neutrophil cytoplasmic antibody positivity: a case-control study. BMJ Open. 2017;7(7):e015668.

16. Li C, Wang JJ, Zhou ML, Liang DD, Yang J, Zhu HX, et al. Differences in clinico-pathological characteristics and outcomes between proteinase 3-ANCA positivity and myeloperoxidase-ANCA positivity in lupus nephritis. Lupus. 2019 Aug;28(9):1111-9.

17. Charney DA, Nassar G, Truong L, Nadasdy T. "Pauciimmune" proliferative and necrotizing glomerulonephritis with thrombotic microangiopathy in patients with systemic lupus erythematosus and lupus-like syndrome. Am J Kidney Dis. 2000 Jun;35(6):1193-206.

18. Kraaij T, Kamerling SWA, Rooij ENM, Van Daele PLA, Bredewold OW, Bakker JA, et al. The NET-effect of combining rituximab with belimumab in severe systemic lupus erythematosus. J Autoimmun. 2018 Jul;91:45-54.

19. Rosenstock JL, Markowitz GS. Fibrillary glomerulonephritis: an update. Kidney Int Rep. 2019 Jul;4(7):917-22.

20. Persellin RH, Takeuchi A. Antinuclear antibody-negative systemic lupus erythematosus: loss in body fluids. J Rheumatol. $1980 \mathrm{Jul} /$ Aug; $7(4): 547-50$. 